\title{
Studies on nucleic acid derivatives in cheese
}

II. The changes of acid-soluble nucleic acid derivatives in Blue, Gouda and Cheddar cheeses during ripening

\author{
Chin-Wen Lin, ${ }^{*}$ Kokichi Taniguchi and Tomokichi Tsugo \\ (Faculty of Agriculture, University of Tokyo) \\ (Received for Publication on May 9, 1968)
}

Cheeses are ripened by rennin and other various enzymes which exist naturally in milk or originate from microorganisms, and their characteristic flavors are produced. It is also considered that the intracellular nucleotides of microorganisms in cheeses are exuded out from cells by autolysis and play partially a role in the specific flavor-production of cheeses.

In the previous paper ${ }^{7}$, the nucleotides found in the white mold cheese after 21 days' ripening were $3^{\prime}$-CMP ( $3^{\prime}$-cytidine monophosphate), cyclic CMP, $5^{\prime}$-UMP ( $5^{\prime}$-uridine monophosphate), GTP (guanosine triphosphate), UTP (uridine triphosphate), ATP (adenosine triphosphate) and CTP (cytidine triphosphate) and their contents were $8.6,13.8,4.7,3.2,4.7$, trace and $25.9 \mu \mathrm{M} / 100 \mathrm{~g}$, respectively. It was also found that the total content of nucleotides. had a close relationship to the stage of cheese-ripening and was presumed that the appearance of these nucleotides in cheeses was originated from the autolysis of microorganisims.

It is known that the starter used and the ripening conditions of cheese are not the same in each cheese, so the pattern of changes of acid-soluble nucleotides may presumably differ in each cheese. In the present work, the authors have carried out a study on the changes of acid-solublenucleic acid derivatives of Blue, Gouda and Cheddar cheeses during ripening.

\section{Methods and Materials}

1. The cheese samples

Blue, Gouda and Cheddar cheeses prepared by the conventional methods were supplied by Snow-Brand Milk Products Co., Ltd. Gouda and Cheddar cheeses were ripened at $15^{\circ} \mathrm{C}$, and Blue cheese at $10^{\circ} \mathrm{C}$ under $80-90 \%$ relative humidity in the ripening room. During the ripening period, the experimental samples were taken periodically and ground in a mortar.

2. Chromatography of acid-soluble nucleic acid derivatives

Twenty grams of ground cheese was extracted by blending with $50 \mathrm{~m} l$ chilled $10 \% \mathrm{HClO}_{4}$ for 5 minutes in a laboratory homogenizer (Nihon Seiki Kogyo, HD-type), and centrifuged for 10 minutes at 2500 r.p.m. The residue was reextracted in the same manner with $50 \mathrm{~m} l$ of $\mathrm{HClO}_{4}$. These extracts, which contained acid-soluble nucleic acid derivatives, were combined and immediately neutralized with $5 \mathrm{~N} \mathrm{KOH}$ to $\mathrm{pH} 6.5$ in an ice-bath. After being kept at $0^{\circ} \mathrm{C}$ for about 30 minutes to permit the complete precipitation of $\mathrm{KClO}_{4}$, the neutralized extract was centrifuged to remove $\mathrm{KClO}_{4}$ and made to $250 \mathrm{~m} l$ with distilled water.

A portion of the neutralized extract was added to the column (Dowex 1-X 8, formate, 200400 mesh, $1 \times 10 \mathrm{~cm}$ ) and then the column was washed with $200 \mathrm{~m} l$ of distilled water before starting the elution. The method of the elution of nucleotides from the column, as shown in

* Present address: Faculty of Agriculture, Meiji University. 
Acid-Soluble nucleotides in cheese

Fig. 1, was similar to that given in the previous report ${ }^{7}$.

Each fraction was absorbed by activated charcoal, washed with $50 \mathrm{ml}$ of $2 \mathrm{~N}$ formic acid and then with water until the washing became neutral. It was finally extracted with $50 \mathrm{~m} l$ of $50 \%$ ethanol containing $2 \%$ ammonia. The extract was concentrated and desalted with Dowex 50$\mathrm{X} 12$ (H-form). The cesalted extract was evaporated to dryness in vacuum and used for paperchromatography.

The solvent systems used were as follows:

A. Iso-propanol: Saturated ammonium sulfate: $0.1 \mathrm{M}$ acetate buffer of $\mathrm{pH} 6.0(2: 79: 19$ by volume)

B. Methanol: $\mathrm{HCl}$ : Ethanol: Water (50:6:25:19 by volume)

C. Iso-butyric acid: $1 \mathrm{~m}$ ammonia: $0.1 \mathrm{~m}$ EDTA ( $100: 60: 1.6$ by volume)

D. Iso-butyric acid: $0.5 \mathrm{M}$ ammonia (10:6 by volume, $\mathrm{pH} 3.6$ )

E. Iso-butyric acid: Water: Acetic acid (100:50:1 by volume)

The solvent systems $\mathrm{A}, \mathrm{B}$ and $\mathrm{C}$ were used for nucleotide monophosphate, $\mathrm{C}, \mathrm{D}$ and $\mathrm{E}$ for nucleotide polyphosphate. The nucleotides were detected on paperchromatograms by using UV light $(253.6 \mathrm{~m} \mu)$.

For the identification of nucleotides, authentic substances were subjected to column and paper chromatography together with the extracts from cheese samples. The determination of the molar ratio of phosphorus to ribose, and the identification of the bases of nucleotides were also done with chromatographically separated fractions. Phosphorus and ribose contents of nucleotides were determined by molybdate reagent method of WeLL-MALHERBE and GREEN ${ }^{12)}$ and the orcinol reagent method of ALBAUN and UMBREIT ${ }^{13}$, respectively. For the identification of the bases of nucleotides, the above mentioned concentrated sample was hydrolyzed with $1 \mathrm{~N} \mathrm{HCl}$ for 1 hour at $100^{\circ} \mathrm{C}$ and submitted to paper chromatography with solvent systems $\mathrm{A}$ and $\mathrm{B}$.

The quantities of nucleotides were estimated by using the following molar absorbancy indices at $\mathrm{pH} 2.0^{111}$ :

Adenosine phosphates $14.2 \times 10^{3}$; Guanosine phosphates $11.8 \times 10^{8}$; Inosine phosphates $7.4 \times$ $10^{3}$; Cytosine phosphates $6.2 \times 10^{3}$

3. Determination of phosphatase activity of cheeses

For the determination of phosphatase activity, the method of BESSEY et al. ${ }^{21}$ was used with a slight modification. One gram of ground cheese was extracted with $50 \mathrm{ml}$ of distilled water by using a homogenizer, and filtered. The filtrate was made to $100 \mathrm{~m} l$ with distilled water and used as an enzyme solution.

Two $\mathrm{m} l$ of buffer solution ( $\mathrm{pH} 10.5$, glycine- $\mathrm{NaOH}$ ), $2 \mathrm{~m} l$ of $0.04 \%$ substrate solution ( $\mathrm{p}$ nitrophenyl phosphate) and $2 \mathrm{~m} l$ of enzyme solution were mixed at $38^{\circ} \mathrm{C}$ and incubated for 60 minutes. Then, $4 \mathrm{ml}$ of $0.5 \mathrm{~N} \mathrm{NaOH}$ was added and the developed color intensity was measured at $420 \mathrm{~m} \mu$.

One $\mu \mathrm{M}$ of p-nitrophenol liberated per gram cheese per hour at $38^{\circ} \mathrm{C}$ was defined as one unit of phosphatase activity.

4. Analysis of cheese

Moisture, titratable acidity, $\mathrm{pH}$, total nitrogen, water soluble nitrogen, ammonia nitrogen and tyrosine were determined by the conventional methods ${ }^{8)}$.

\section{Results and Discussion}

The changes of chemical composition of Blue, Gouda and Cheddar cheeses during ripening 
were shown in Tables 1, 2 and 3.

From these results the ripening of the cheeses is considered to have proceeded normally. The most suitable ripening periods were 60 days for Blue cheese and 120 days for Gouda and Cheddar cheeses, respectively, when judged from flavor and taste of cheeses.

Table 1. The changes of chemical composition of Blue cheese during ripening

\begin{tabular}{|c|c|c|c|c|c|c|c|}
\hline Period of ripening (days) & 0 & 10 & 20 & $30^{.87}$ & 40 & 60 & 90 \\
\hline Moisture & 42.74 & 42.16 & 43.72 & 43.56 & 43.52 & 42.45 & 41.51 \\
\hline Acidity* & 2.61 & 2.57 & 1.71 & 1.53 & 1.44 & 1.35 & 1.35 \\
\hline Protein & 20.55 & 21.76 & 22.20 & 21.44 & 21.63 & 21.76 & 22.65 \\
\hline $\mathrm{pH}$ & 4.9 & 4.9 & 5.7 & 6.5 & 6.9 & 7.2 & 7.5 \\
\hline Total nitrogen & 3.22 & 3.41 & 3.48 & 3.36 & 3.39 & 3.41 & 3.55 \\
\hline $\begin{array}{l}\text { Water soluble } \\
\text { nitrogen }(\%)\end{array}$ & 0.32 & 0.37 & 0.90 & 1.31 & 1.58 & 1.73 & 2.13 \\
\hline Ammonia nitrogen $(\%)$ & 0.04 & 0.06 & 0.07 & 0.15 & 0.21 & 0.24 & 0.43 \\
\hline Tyrosine & 60.0 & 68.0 & 135.0 & 205.0 & 225.0 & $230.0^{\circ}$ & 425.0 \\
\hline Ripening ratio ${ }^{* *}$ & 10.04 & 10.85 & 25.86 & 38.99 & 46.61 & 50.73 & 60.00 \\
\hline
\end{tabular}

* Calculated as lactic acid

** Ripening ratio: water soluble nitrogen/total nitrogen $\times 100$

Table 2. The changes of chemical composition of Gouda cheese during ripening

\begin{tabular}{|c|c|c|c|c|c|c|c|}
\hline Period of ripening (days) & 0 & 30 & 60 & 90 & 120 & 150 & 180 \\
\hline Moisture & 38.72 & 36.96 & 36.60 & 34.55 & 35.82 & 36.75 & 36.82 \\
\hline Acidity & 0.72 & 1.35 & 2.12 & 1.80 & 1.89 & 1.80 & 2. 16 \\
\hline Protein & 27.37 & 28.26 & 28.84 & 28.90 & 27.94 & 28.52 & 28.14 \\
\hline $\mathrm{pH}$ & 5.9 & 5.9 & 5.8 & 5.9 & 5.9 & 5.9 & 5.8 \\
\hline Total nitrogen $(\%)$ & 4.29 & 4. 43 & 4.52 & 4.53 & 4.38 & 4.47 & 4.41 \\
\hline $\begin{array}{l}\text { Water soluble } \\
\text { nitrogen } \quad(\%)\end{array}$ & 0.38 & 0.75 & 1.22 & 1.25 & 1.23 & 1.34 & 1.35 \\
\hline Ammonia nitrogen $(\%)$ & 0.05 & 0.06 & 0.08 & 0.10 & 0.10 & 0.10 & 0.09 \\
\hline Tyrosine & 36.0 & 72.0 & 96.0 & 120.0 & 145.0 & 155.0 & 160.0 \\
\hline Ripening ratio $(\%)$ & 8.81 & 16.93 & 26.99 & 27.59 & 28.08 & 29.98 & 30.61 \\
\hline
\end{tabular}

Table 3. The changes of chemical composition of Cheddar cheese during ripening

\begin{tabular}{|c|c|c|c|c|c|c|c|}
\hline Period of ripening (days) & 0 & 30 & 60 & 90 & 120 & 150 & 180 \\
\hline Moisture & 36.07 & 37.08 & 36.27 & 36.20 & 36.34 & 37.01 & 36.12 \\
\hline Acidity & 1.08 & 2.79 & 2.61 & 2.16 & 2.16 & 2.07 & 2.16 \\
\hline$(\%)$ & 27.16 & 27.31 & 27.82 & 27.94 & 27.12 & 27.37 & 27.70 \\
\hline $\mathrm{pH}$ & 5.5 & 5.4 & 5.4 & 5.6 & 5.5 & 5.6 & 5.5 \\
\hline Total nitrogen $(\%)$ & 4.25 & 4.28 & 4.36 & 4.38 & 4.25 & 4.29 & 4.34 \\
\hline $\begin{array}{l}\text { Water soluble } \\
\text { nitrogen } \quad(\%)\end{array}$ & 0.79 & 0.89 & 0.97 & 1.03 & 1.01 & 1.07 & 1.22 \\
\hline Ammonia nitrogen $(\%)$ & 0.05 & 0.06 & 0.08 & 0.09 & 0.10 & 0.10 & 0.07 \\
\hline Tyrosine & 51.0 & 77.0 & 108.0 & 132.0 & 155.0 & 165.0 & 205.0 \\
\hline Ripening ratio & 18.59 & 20.79 & 22.31 & 23.52 & 23. 75 & 24.94 & 28.11 \\
\hline
\end{tabular}




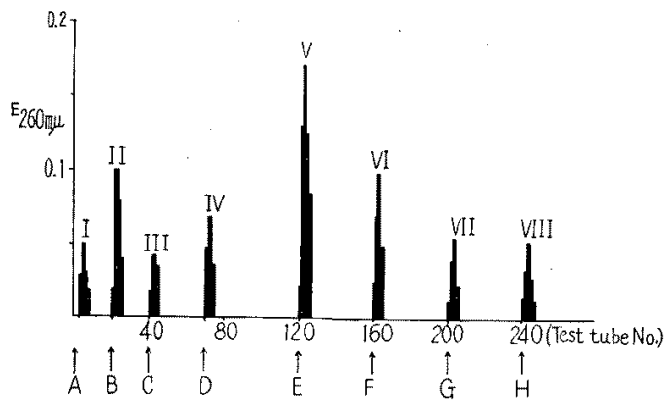

Fig. 1. Elution pattern of acid-soluble nucleic acid derivatives of Blue cheese $(20 \mathrm{~g})$ ripened for 60 days on the column chromatography

The column chromatography was carried out using a column $(1.0 \times 10$ $\mathrm{cm}$ ) containing an anion exchange resein Dowex 1-X 8 (200-400 mesh) formate form. Flow rate was $1.5 \mathrm{~m} l$ per minute. Each $10 \mathrm{~m} l$ fraction was collected in a tube.

Elution solutions were as follows: $A, 0.005 \mathrm{M}$ formic acid (FA). B, $0.02 \mathrm{M}$ FA. C, $0.1 \mathrm{M}$ FA. D, 0.1 м FA +0.1 sodium formate $(\mathrm{FNa}) . \mathrm{E}, 0.1 \mathrm{M}$ FA +0.6 м FNa. F, 0.1 м FA+0.8 м FNa. G, 0.5 M FA +1.0 M FNa. H, $2.0 \mathrm{MFA}+1.0 \mathrm{M} \mathrm{FNa}$

I, Inosine; II, 5'-CMP; III, 5'-AMP; IV, 5'-IMP; V, GTP VI, ADP; VII, ATP; VIII, Guanosine

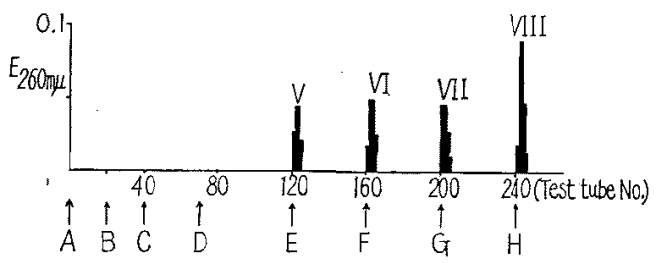

Fig. 2. Elution pattern of acid-soluble nucleic acid derivatives of Gouda cheese $(20 \mathrm{~g})$ ripened for 120 days on the column chromatography

The conditions of column chromatography were the same as given in Fig. 1.

V, GTP; VI, ADP; VII, ATP; VIII, Guanosine

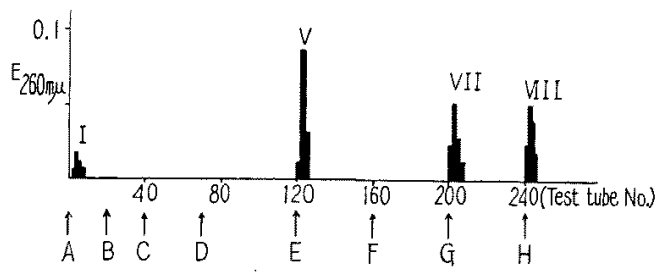

Fig. 3. Elution pattern of acid-soluble nucleic acid derivatives of Cheddar cheese $(20 \mathrm{~g})$ ripened for 120 days on the column chromatography

The conditions of column chromatography were the same as given in Fig. 1.

I, Inosine; V, GTP; VII, ATP; VIII, Guanosine

Fig. 1,2 and 3 represent the elution patterns of acid-soluble nucleic acid derivatives of Blue (ripened for 60 days), Gouda and Cheddar (ripened for 120 days) cheeses, respectively. In these patterns, the acid-soluble nucleic acid derivatives identified by paper chromatography 


\section{Lin - Taniguchi $\cdot$ Tsugo}

and the estimation of the molar ratio among base, ribose and phosphorus were as follows: $I$. inosine, II. 5'-CMP, III. 5'-AMP (5'-adenosine monophosphate), IV. 5'-IMP (5'-inosine monophosphate), V. GTP, VI. ADP (adenosine diphosphate), VII. ATP, VIII. guanosine. The identified acid-soluble nucleic acid derivatives in cheeses were nucleotides except two nucleotides of inosine and guanosine. In this report, for convenience, the ASND stands for the acid-soluble nucleic acid derivatives.

The changes of ASND of Blue cheese during 90 days' ripening were shown in Table 4. In the early stage of ripening, seven ASND were detected, five of which were adenine derivatives, namely, ATP, ADP, 5'-AMP, 5'-IMP and inosine. The content of $5^{\prime}$-IMP increased from 1.9 $\mu \mathrm{M}$ at the beginning day of ripening to its maximum value of $3.1 \mu \mathrm{M}$ after 30 days' ripening, then decreased to $1.4 \mu \mathrm{M}(0.5 \mathrm{mg} \%$ in cheese) after 40 to 60 days' ripening, and again slightly increased after 90 days' ripening. The total content of ASND was the largest after 10 days' ripening $(41.6 \mu \mathrm{M} / 100 \mathrm{~g})$. With the changes of the total content of ASND the growth of ino-

Table 4. The changes of contents of acid-soluble nucleic acid derivatives (ASND) in Blue cheese during ripening

\begin{tabular}{|c|c|c|c|c|c|c|c|c|}
\hline \multirow{3}{*}{ Fraction } & \multirow{3}{*}{ ASND } & \multicolumn{7}{|c|}{ Period of ripening (days) } \\
\hline & & 0 & 10 & 20 & 30 & 40 & 60 & 90 \\
\hline & & \multicolumn{7}{|c|}{$-\mu \mathrm{M} / 100 \mathrm{~g}-$} \\
\hline $\mathrm{I}$ & Inosine & 3.4 & 4.2 & 0.6 & 0.8 & 0.8 & 0.7 & 0.7 \\
\hline II & $5^{\prime}-\mathrm{CMP}$ & & & & 0.2 & 0.3 & 0.6 & 0.8 \\
\hline IIII & $5^{\prime}-\mathrm{AMP}$ & 3.7 & 2.6 & 0.3 & 0.7 & 0.6 & 0.4 & 0.7 \\
\hline $\mathrm{IV}$ & $5^{\prime}-\mathrm{IMP}$ & 1.9 & 2.0 & 1.7 & 3.1 & 1.4 & 1.4 & 2.0 \\
\hline $\mathrm{V}$ & GTP & 5.8 & 22.1 & 7.9 & 3.4 & 3.3 & 2.7 & 3.6 \\
\hline $\mathrm{VI}$ & $\mathrm{ADP}$ & 1.1 & 1.2 & 0.4 & 1.6 & 1.0 & 0.8 & 2.2 \\
\hline VII & ATP & 3.9 & 3.2 & 5.5 & & & 0.5 & 1.5 \\
\hline VIII & Guanosine & 2.6 & 1.3 & 1.7 & & & 1.2 & 1.3 \\
\hline & Total & 22.4 & 41.6 & 18.1 & 9.8 & 7.4 & 8.3 & 12.8 \\
\hline
\end{tabular}

Table 5. The changes of contents of acid-soluble nucleic acid derivatives (ASND) in Gouda cheese during ripening

\begin{tabular}{|c|c|c|c|c|c|c|c|c|}
\hline \multirow{3}{*}{ Fraction } & \multirow{3}{*}{ ASND } & \multicolumn{7}{|c|}{ Period of ripening (days) } \\
\hline & & 0 & 30 & 60 & 90 & 120 & 150 & 180 \\
\hline & & \multicolumn{7}{|c|}{$-\mu \mathrm{M} / 100 \mathrm{~g}-$} \\
\hline I & Inosine & 4.3 & 3.9 & & & & & \\
\hline II & $5^{\prime}-\mathrm{CMP}$ & 2.8 & 0.5 & & & & & \\
\hline III & $5^{\prime}$-AMP & 1.9 & & & & & & \\
\hline IV & $5^{\prime}$-IMP & 4.2 & & & & & & 0.7 \\
\hline $\mathrm{V}$ & GTP & 2.3 & 0.7 & 0.5 & 0.5 & 0.4 & 0.6 & 0.8 \\
\hline VI & $\mathrm{ADP}$ & & & & & 0.3 & 0.3 & 0.2 \\
\hline VII & ATP & & 1.2 & 0.5 & 0.4 & 0.3 & 0.4 & 0.2 \\
\hline \multirow[t]{2}{*}{ VIII } & Guanosine & & & 1.9 & 1.6 & 1.4 & 1.4 & 1.3 \\
\hline & Total & 15.5 & 6.3 & 2.9 & 2.5 & 2.4 & 2.7 & 3.2 . \\
\hline
\end{tabular}


Acid-Soluble nucleotides in cheese

Table 6 . The changes of contents of acid-soluble nucleic acid derivatives (ASND) in Cheddar cheese during ripening

\begin{tabular}{|c|c|c|c|c|c|c|c|}
\hline \multirow{3}{*}{ Fraction } & \multirow{3}{*}{ ASND } & \multicolumn{6}{|c|}{ Period of ripening (days) } \\
\hline & & 0 & 30 & 60 & 90 & 120 & 180 \\
\hline & & \multicolumn{6}{|c|}{$-\mu \mathrm{M} / 100 \mathrm{~g}-$} \\
\hline $\mathrm{I}$ & Inosine & 5.7 & 4.5 & 0.5 & 0.4 & 0.3 & 0.8 \\
\hline II & $5^{\prime}-\mathrm{CMP}$ & 0.3 & 0.3 & & & & 0.3 \\
\hline III & $5^{\prime}$-AMP & & & & & & 0.4 \\
\hline IV & $5^{\prime}-\mathrm{IMP}$ & & & & & & 0.6 \\
\hline V & GTP & 2.4 & 0.7 & 2.2 & 0.3 & 0.7 & 0.8 \\
\hline $\mathrm{VI}$ & ADP & 0.8 & 0.4 & 0.8 & 0.3 & & 0.4 \\
\hline VII & ATP & & & 2.1 & 0.4 & 0.6 & \\
\hline VIII & Guanosine & & & 3.7 & 1.1 & 1.0 & \\
\hline & Total & 9.2 & 5.9 & 9.3 & 2.5 & 2.6 & 3.3 \\
\hline
\end{tabular}

culated Penicillium roqueforti seems to have been correlated. Namely, since the growth of $P$. roqueforti is known to become evident inside the cheese within 8 to 10 days' ripening and gradually propagate to reach its maximum development throughout the curd particles within 30 to 90 days' ripening ${ }^{8}$, for the mold propagation ASND derived from the autolysed cells were probably utilized rapidly at the earlier stage of ripening, after which a slight decrease in the ASND content followed, but as the growth of mold was presumably limited at the further advanced stage of ripening, the content of ASND slightly increased again after 90 days' ripening.

Table 5 represents the changes of ASND in Gouda cheese. At every ripening period, 3 to 5 ASND were detected. In the early stage of ripening, nucleotide monophosphates occupied most part of the total ASND, but as the ripening proceeded they disappeared, and replacing them nucleotide polyphosphates appeared. As an exception, $5^{\prime}$-IMP was found in both of the cheeses ripened for 0 and 180 days, and its content was 4.2 and $0.7 \mu \mathrm{M}$, respectively. The total content of ASND was the largest (15.5 $\mu \mathrm{M}$ ) at the beginning day of ripening.

Table 6 shows the changes of ASND in Cheddar cheese. The ASND in cheese ripened for 60-120 days belonged mostly to nucleotide polyphosphates. In the cheese ripened for 180 days, three nucleotide monophosphates, including $5^{\prime}$-IMP, appeared. That the total content of ASND was the largest in the green Cheddar cheese at the beginning day of ripening was similar to Gouda cheese. In Gouda and Cheddar cheeses, ASND were supposed to be originated from the starter organisms, and in both cheeses the total content of ASND tended to decrease with the ripening period in general and to increase again slightly at the final stage of ripening in a similar manner.

During the ripenig of Blue, Gouda and Cheddar cheeses, eight kinds of ASND were found. Five of them were adenine derivatives. The following pathway of adenine derivatives have been known in the process of autolysis of tissue of fish: ATP $\rightarrow$ ADP $\rightarrow$ MMP $\rightarrow I M P \rightarrow$ inosine $e^{5)}$. This pathway, however, was not clearly observed in this study of cheese ripening. Probably because the autolysis and metabolism of microorganisms had proceeded simultaneously, any appreciable amount of 5'-IMP may have not accumulated.

In this study, though $5^{\prime}$-IMP which is an important flavoring constituent of aninal tissue was found in cheeses, its amount was far below the threshold value of taste $(0.0125 \%)$. 
But, as synergistic action is known between $5^{\prime}$-IMP and monosodium L-glutamate ${ }^{6)}$ the threshold value 5'-IMP may have presumably been reduced in the presence of free glutamic acid produced by the ripening of cheese, and $5^{\prime}$-IMP may have exhibited some effects on the flavor of cheese.

It is known that physical, chemical and microbiological changes take place throughout the ripening period in all kinds of cheeses Fig. 4 and 5 represent the changes of the ripening ratio, tyrosine content and total content of ASND.

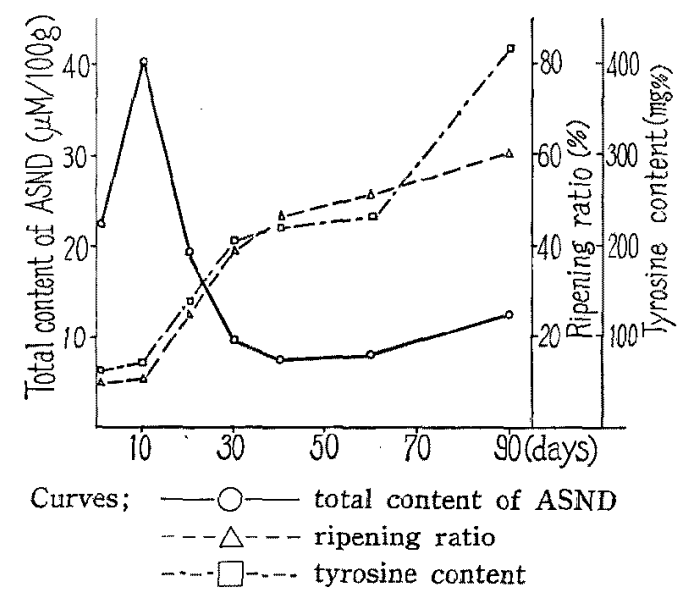

Fig. 4. The changes of total content of acid-soluble nucleic acid derivatives (ASND), ripening ratio and tyrosine content in Blue cheese

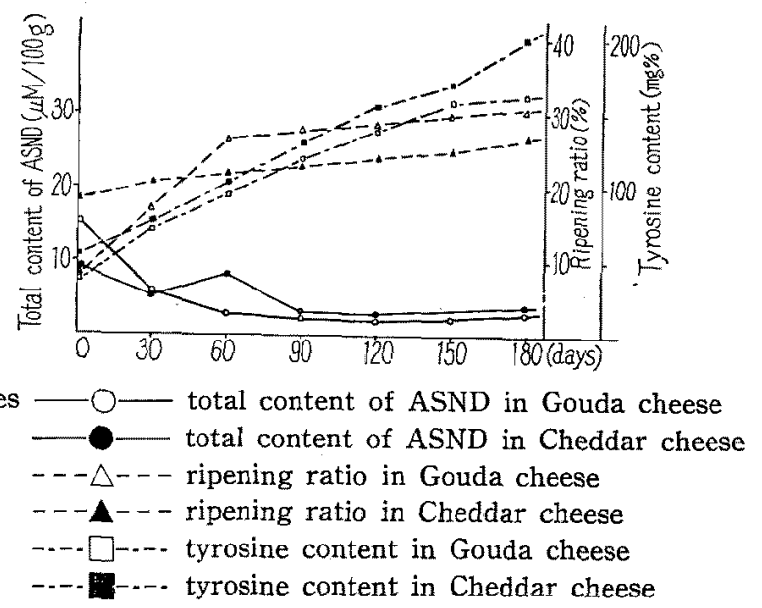

Fig. 5. The changes of total content of acid-soluble nucleic acid derivatives (ASND), ripening ratio and tyrosine content in Gouda and Cheddar cheeses

These results showed that the total content of ASND in each cheese varied in its respectively different manner, while the tyrosine content increased consistently in all cheeses with the ripening period. The variation of ASND content may have probably been due to the microbiological changes. In comparison with other unripened or over-ripened cheeses, the content of total ASND of moderately ripened cheeses usually stands lower. In Blue cheese, the growth of $P$. roqueforti is evident after 8 or 10 days' ripening ${ }^{8 ?}$. The maximum amount of total ASND 
Acid-Soluble nucleotides in cheese

in Blue cheese was observed at 10 days' ripering. In Gouda and Cheddar cheeses, where only lactic acid starter is used, the number of lactic acid bacteria is said to decrease during ripening ${ }^{4}$. In Fig. 5, the content of ASND decreased gradually during ripening.

Because ASND are thought to have been derived from microbial cells, it is natural that the content of ASND in Blue cheese, in which a great number of fungi cells are present, is larger than those in Gouda and Cheddar cheeses. In Gouda and Cheddar cheeses, ASND seemed to be nothing but minor components.

As the ripening proceeded, the decrease in the content of ASND was observed. The presence of phosphatase, which decomposes nucleotides to nucleosides, is supposed to be one of the causes of the decrease in ASND. The changes of phosphatase activities in cheeses during ripening were shown in Tables 7 and 8 .

Table 7. The changes of phosphatase activities in Blue cheese during ripening

\begin{tabular}{l|cccccc}
\hline Period of ripening (days) & 0 & 10 & 20 & 30 & 40 & 60 \\
\hline The phosphatase activities* & 0.15 & 0.16 & 0.22 & 0.22 & 0.28 & 0.28 \\
\hline
\end{tabular}

* Expressed as $\mu \mathrm{M}$ of p-nitrophenyl liberated trom buffer substrate ( $\mathrm{pH}$ 10.5) per gram of cheese sample per hour at $38^{\circ} \mathrm{C}$

Table 8. The changes of phosphatase activities in Gouda and Cheddar cheeses during ripening

\begin{tabular}{c|ccccccc}
\hline $\begin{array}{c}\text { Period of ripening (days) } \\
\text { The phosphatase activities }\end{array}$ & 0 & 30 & 60 & 90 & 120 & 150 & 180 \\
$\begin{array}{c}\text { Gouda } \\
\text { Cheddar }\end{array}$ & 0 & 0 & 0 & 0 & 0 & 0 & 0 \\
& 0.50 & 0.47 & 0.40 & - & 0.19 & 0.17 & 0.20 \\
\hline
\end{tabular}

* Expressed in the same manner as described in Table ?.

The phosphatase activity was noticed in both cheeses of Blue and Cheddar, but not in Gouda cheese. During ripening, the phosphatase activity increased in Blue cheese, but decreased in Cheddar cheese. This difference seemed to correlate to the changes of the number of microbial cells during ripening, that is, in Blue cheese, $P$. roqueforti may have continued to grow, while, in Cheddar and Gouda cheeses, the number of lactic acid bacteria may have decreased ${ }^{4}$.

In Gouda cheese, in spite of no phosphatase acitivity, the decrease of ASND was observed. Besides phosphatase, in this case, the utilization of ASND by microorganisms may be considered as a cause of the decrease in ASND. It has been reported by TSUGO and TANIGUCHI ${ }^{91}$ and TANIGUCHI et al. ${ }^{101}$ that some kinds of nucleotides are utilized as growth stimulant by lactic acid bacteria.

Many factors, such as the number of microbial cells, the decomposition by phosphatase or utilization by microorganisms, affect the changes of ASND in cheese, and the decreasing tendency of ASND with ripening period as shown in Fig. 4 and Fig. 5, indicates that the amount. of ASND decomposed or utilized was larger than that derived from microbial cells. When the growth of microorganisms is very prominent, the amount of ASND derived from cells may overcome that of ASND decomposed or utilized. An example of this is the semi-soft white mold cheese, in which ASND continued to increase linearly during one month's ripening to reach such a fairly large amount of $120 \mu_{\mathrm{M}}$ per $100 \mathrm{~g}_{\text {cheese }} \mathrm{c}^{7}$.

\section{Summary}

The acid-soluble nucleic acid derivatives appeared in Blue, Gouda and Cheddar cheeses 


\section{Lin - Taniguchi * Tsugo}

during ripening were fractionated by ion-exchange column chromatography. Each fraction obtained was identified by means of determining phosphorus, ribose and bases, and subrnitting to paper chromatography.

The acid-soluble nucleic acid derivatives detected in these cheeses throughout the ripening period were inosine, 5'-CMP, 5'-AMP, 5'-IMP, GTP, ADP, ATP and guanosine. The total content of these compounds of moderately ripened Blue, Gouda and Cheddar cheeses was 8.3, 2.4 and $2.6 \mu_{\mathrm{M}}$ per $100 \mathrm{~g}$, respectively, and the majority of them were affiliated to adenine derivatives. The amount of $5^{\prime}$-IMP which is known as a flavoring component found in Blue cheese was far below the threshold value of taste. But by the synergistic action of glutamic acid presumably coexisting in cheese, 5'-IMP may have exhibited some favorable effect on cheese flavor.

\section{Acknowledgement}

The authors wish to thank Snow-Brand Milk Products Co., Ltd. for the donation of cheese samples, and to Dr. U. Yoshino and Dr. H. Matsuoka for their valuable advices and discussions.

\section{References}

1) Albaum, H.G. and W.W. Umbreit (1947) J. Biol. Chem., 167: 369-376.

2) Bessey, O.A., O.H. Lowry and J.M. Broch (1946) J. Biol. Chem., 164: 321-329.

3) Foster, E.M., M.L. Speck, F.E. Nelson, R.N. Doetsch and J.C. Olson, JR. (1957) Dairy Microbiology, P. 390 Prentice-Hall, Inc. New Jersey.

4) Hammer, B.W. and F.J. Babel (1957) Dairy Bacteriology, Fourth Edition P. 518 John Wiley \& Sons, Inc. New York.

5) Kassemsarn, B., B.S. Perez, J. Murray and N.R. Jones (1963) J. Food Sci., 28: 28.

6) Kunimaka, A. (1960) J. Agric. Chem. Soc. Jap., 34: 489-492.

7) Tsugo, T., K. Taniguchi and C.W. LiN (1967) Jap. J. Zootech. Sci., 38: 18-23.

8) Tsugo, T., K. Taniguchi and Y. Kawaguchi (1964) Jap. J. Zootech. Sci., 35: 290-295.

9) Tsugo, T. and K. Taniguchi (1962) Jap. J. Zootech Sci., 33: 130-135.

10) Taniguchi, K., A. NAgao and T. Tsugo (1965) Jap. J. Zootech. Sci., 36: 376-383.

11) Volkin, E. and W.E. CoHn (1954) Methods of Biochemical Analysis, Interscience Publishers. Inc. New York, I: 287.

12) Well-Malherbe, H. and R.H. Green (1951) Biochem. J., 49: 286-292. 


\section{チーズ中の核酸関連物質に関する研究}

II. ブルー、ゴーダおよびチェダーチーズの熟成中における酸可溶性核酸関連物質の变化

\section{林慶文・谷口宏吉*.津 郷友吉}

(東京大学農学部)

熟成中に新けるブルー，ゴーダおよびチェダーチーズ の酸可溶性核酸関連物質を陰イオン交換樹脂，(Dewex 1-X8，ぎ酸型，メッシュ200〜400) を用いたカラムタ ロマトグラフィーにより分別し，各画分について、り ん，糖，㙉基の分析およびペーパークロマトグラフィー によって各核酸関連物質空確悲定量した。この3つの千 一ズ中に存在する酸可溶性核酸関連物質はイノシン, $5^{\prime}-$ CMP, 5'-AMP, 5'-IMP, GTP, ADP, ATP お上びグ

* 琵在：明治大学樶学部
アノシンの 8 種で，これら核酸関連物質は主としてアデ ニン系に属主る。これらのうち，呈味成分として知られ ている 5'-IMPの量はブルーチーズに秃いてもっとも多 かった。 午の量は 5'-IMPの呈昧の閾值より低いが，千 一ズ中では熟成の結果生成したグルタミン酸との相渠効 果も考兄られ，チーズ風味に影響する可能性がある。 た遖度の熟成状態にあるブルー、ゴーダおよびチェダー チーズの酸可溶性核酸関連物質の全量は $100 \mathrm{~g}$ 当りそれ ぞれ 8.3，2.4抽び $2.6 \mu_{\mathrm{M}}$ であった。 